\title{
The Effect of Internal Control on Fraud Trends in Financial Statements with Exoteric Religiosity and Esoteric Religiosity as Moderating Variables
}

\author{
Izzul Ashlah \\ Magister Program of Economics and Business Faculty, Jember University-Indonesia \\ Whedy Prasetyo \\ Economics and Business Faculty, Jember University-Indonesia \\ Muhammad Miqdad \\ Economics and Business Faculty, Jember University-Indonesia
}

\begin{abstract}
This study aims to examine and analyze the effect of internal control on fraud tendencies in financial statements with exoteric religiosity and esoteric religiosity as a moderating variables. The method used in this study uses a quantitative method with 32 samples. The results of this study indicate that internal control has a negative effect on fraud tendencies in financial statements and exoteric religiosity and esoteric religiosity variables moderate the relationship between the two.
\end{abstract}

Keywords: Internal Control, Fraud, Religiosity, Exoteric, Esoteric, Financial Statements

DOI: $10.7176 /$ RJFA/11-16-15

Publication date:August $31^{\text {st }} 2020$

\section{Introduction}

Many cases of fraud occur in large organizations with established internal controls (Ferrell \& Fraedrich, 2015). Fraud in the financial statements that occurred in Indonesia was carried out by PT. Great River International, Tbk. The results of the examination of the Capital Market Supervisory Agency (Bapepam) showed that there were indications of fraud in the presentation of financial statements, in which Bapepam found an excess of recording the presentation of sales and accounts receivable. PT Kereta Api Indonesia (PT KAI)'s annual financial performance report announced that PT KAI had a profit of Rp. 6.90 billion, when in fact there was a loss of Rp. 63 billion. These cases are examples or a small number of fraud cases in financial statements.

The increased fraud cases lead to moral and ethical problems in the world of practice. Moral, ethics and accounting control environment are two very important things related to one's tendency to commit financial fraud (Hernandez \& Groot, 2007). Morals and ethics stem from the influence of religious values that are trusted by individuals. Topics about the influence of religion and accounting have not been explored more widely in the conventional literature, although it is not difficult to see how they can be connected (Carmona \&Ezzamel, 2006; Lewis, 2001).

In general, accounting cannot be separated from the existing culture (Gray, 1988; Perera, 1989). Culture is the whole system of ideas, actions, and results of human work in the framework of people's lives, therefore if culture influences accounting then certainly also with religion, because religion influences cultural norms (Hamid et al, 1993). According to McGuire et al (2011) understanding the impact of religion on accounting, especially financial reports, is important because cultural norms are known to have a strong influence on human behavior. Religion is actually a non-material social fact that allows it to be used to highlight the whole aspect (Durkheim, 1995; Ritzer, 1998), but modern social science in dissecting phenomena has a tendency to only use a materialist approach, so that non-material symptoms such as religion or trust is seen as a secondary symptom.

Normatively, religion should be able to control the behavior of fraud followers. Internal controls are not solely manual policies and involve various forms but involve individuals within the organization. The success of a system goes well and effectively cannot be separated by individual factors. Religion must be the basis of individual behavior in financial reporting (Triyuwono et al, 2016), thus individuals holding religion will present financial statements accountably and transparently (Dyreng et al, 2012).

\section{Theoretical Foundation}

\subsection{Internal Control}

Internal controls are policies and procedures that help to ensuring the management orders have been made. Control activities help to ensure that actions are needed regarding the risks taken to achieve organizational goals. The indicators used are five components of internal control, namely the control environment, risk assessment, control activities, information and communication and monitoring (Arens et al, 2015). 


\subsection{Fraud}

Fraud is any illegal and intentional act in non-physical ways that are characterized by fraud, concealment or breach of trust. The indicators used are three typologies of fraud, namely deviations of assets, false statements or financial statement engineering and corruption (ACFE, 2016).

\subsection{Exoteric Religiosity}

Exoteric religiosity is an outward teaching in the form of symbols, attributes, accessories, and other legal forms of formality. Exoteric religiosity emphasizes the form and tendency of literalistic dogma, claims of exclusive ownership of truth, and considers religion to be useful for personal salvation (Schuon, 1998; Siradj, 2006). Darviri et al (2014) also suggested that the orientation of exoteric religiosity was given to the outward appearance of religion, tangible, ritualized and institutionalized aspects of religion which were widely regarded as a sign of obedience in culture.

\subsection{Esoteric Religiosity}

Esoteric religiosity has the meaning of aspects in the heart, essence, core or substance, as opposed to external aspects, aspects of birth, aspects of shari'a, and material aspects. The esoteric dimension is more focused on religious substances which cannot be legally captured (Siradj, 2006). The characteristic of the esoteric dimension is that individuals try to find the essence of religion.

\subsection{Broken Windows Theory}

Broken Windows Theory is a study of James Q. Wilson and George L. Kelling which shows that if small crimes or irregularities are left without any control or follow-up resolution, more people will do the same thing and even cause crime on a larger scale (Braga \& Welsh, 2016). The name of the theory is derived from the observation that several broken windows in the settlement triggered people to break other windows, carry out vandalism and even break in. So, a broken window will provoke people to break other windows and if it is let as it isthere might be a fire inside. This condition will later provoke the criminals to come in this area and then take control of it.

Broken Windows theory explains that crime is an inevitable result of disorder. Starting with small actions, irregularity is an invitation to do more serious crimes. This is an epidemic theory for crime. According to this theory, fraud is contagious just like the fashion trend so that with a small start, such as breaking a window, the same action immediately spreads throughout the region. Therefore, when there is no control over these actions, it will result in a larger scale.

\subsection{Planned Behavior Theory}

Theory of planned behavior (TPB) is a theory that explains individual factors in behavior (Ajzen, 2006). TPB provides an explanation that before individuals behave there are influencing factors so that the intention arises and finally becomes a behavior. Intention to conduct a behavior can be measured through three main predictors that influence the intention, namely attitude toward the behavior, subjective norms, and perceived behavioral control (Ajzen, 2006).

Attitude toward the behavior basing the more individuals have an assessment that a behavior will produce positive consequences, the individual will tend to follow the behavior; on the contrary, the more individuals have an assessment that a behavior will produce negative consequences, the individual will tend to reject the behavior.

Subjective norms are based on the more individuals perceive that social referrals recommend to do a behavior so individuals will tend to feel the social pressure to do the behavior; on the contrary, the more individuals perceive that the social referral recommends not to do a behavior then the individual will tend to feel social pressure not to do the behavior.

Perceived behavioral control basing as a function based on a belief called control beliefs, namely individual beliefs about supporting factors and/or inhibitors to perform a behavior. Belief about supporting and inhibiting factors to conduct a behavior is based on the individual's experience of a behavior, information that an individual has about a behavior that is obtained by observing knowledge possessed by himself or others who are known to individuals, and also by various other factors that can increase or decrease individual feelings about the level of difficulty in carrying out a behavior.

\subsection{Stewardship Theory}

Stewardship theory that describes a situation where management is not motivated by individual goals but rather aimed at their main outcome goals for the benefit of the organization (Donaldson \& Davis, 1991; Podrug, 2011)). The theory assumes that there is a strong relationship between organizational satisfaction and success. Organizational success describes the maximization of utility of principal groups and management. The maximization of the utility of this group will ultimately maximize the interests of individuals within the group of organizations. 
Ownership functions with management functions are separated in an organization. The resource owner (principal) entrusts the management of these resources to other parties who are better prepared. Contract relationships between stewards and principals on the basis of trust, act collectively in accordance with organizational goals. Stewardship theory is often referred to as management theory (stewardship) with several basic assumptions.

\section{HypothesisDevelopment}

\subsection{Internal Control and Fraud Tendencies in Financial Statements}

Broken Windows theory explains that if small frauds or irregularities are left without prevention, control or follow-up resolution, more people will do the same thing and even cause crime on a larger scale (Braga \& Welsh, 2016). Fraud is contagious just like the fashion trend so that with a small start, such as breaking a window, the same action immediately spread throughout the place. Therefore, in dealing with fraud, effective prevention and control is needed. Organizations can fix this problem by carrying out a systematic approach to internal control (Mumtaz, 2018), with five control components designed and implemented by management to provide reasonable assurance that the control objectives will be achieved, i.e. the control environment, risk assessment, control activities, information and communication and monitoring (COSO, 2013).

Research by Smith et al. (1997), Abbot et al. (2004), Wilopo (2006), Dewi (2014), Udayani (2017) states that effective internal controls can reduce financial report fraud. Fama (1980), and Brick \&Chidambaran (2004) explain that principals can solve agency problems by issuing monitoring costs. Good monitoring results require effective company internal control. AICPA (2007) explains that internal control is very important, among others, to provide protection for entities against human weaknesses and to reduce the possibility of errors and actions that are not in accordance with the rules, thus properly implemented and effective internal controls can reduce or even close opportunities to carry out financial report fraud in agencies or institutions that can harm the institution or institution itself.

H1: Internal control influences the tendency of fraud in financial report

\subsection{Exoteric Religiosity, Internal Control and the Tendencies of Fraud in Financial Statements}

Many cases of fraud occur in large organizations with established internal controls. The relationship of internal control and financial reporting involves many aspects of behavioral accounting (Al-Aidaros, 2012; Salman \& Kareem, 2012). The internal control system is much influenced by contextual factors, one of which is individual factors (Suartana, 2010). Internal controls are not solely manual policies and involve various forms but involve individuals within the organization. The success of a system goes well and effectively cannot be separated by individual factors.

Relations between religion and accounting are actually not difficult to see (Carmona \&Ezzamel, 2006; Lewis, 2001). One dimension of religion is the exoteric dimension.Exoteric dimension is an outward form of symbols, attributes, accessories, and other forms of legal formality (Schuon, 1998; Siradj, 2006). Exoteric dimension emphasizes the outward appearance of religion, in the form of ritual and institutionalization of religion which is widely regarded as a sign of obedience in culture (Darviri et al, 2014).

Exoteric traditions in religion besides aiming as a form of obedience to God also have social goals. The existence of merit and sin concept in the exoteric tradition is intended to inspire humans to behave socially, in other words to behave in favor of order and productivity in society. Religious rituals as an exoteric dimension have authority affecting the behavior of adherents (Lakonawa, 2013). Rituals actualize symbols into sacred actions. Through rituals, symbols are lived and celebrated. Rituals play an important role in bringing together all of its followers. Rituals are very effective in establishing a religious identity of a particular religion and increasing social ties with whom they share their views and the fact that their lives have meaning and structure.

The concept of reward and sin in the exoteric dimension becomes the main driver of individuals behaving. TPB provides an illustration that before individuals behave there are influencing factors that lead to intentions and finally behavior. One predictor that influences intention and behavior according to Ajzen (2006) is attitude toward the behavior. The more individuals have an assessment that a behavior will produce positive consequences, the individual will tend to be active towards the behavior; on the contrary, the more individuals have an assessment that a behavior will produce negative consequences, the individual will tend to reject the behavior (Ajzen, 2006).

Seeing that internal control is not merely a manual policy and involves various forms but involves individuals within the organization. The success of a system goes well and effectively cannot be separated by individual factors. Therefore, the exoteric dimension in religion which has a role in forming human perspectives and behavior will strengthen the relationship of internal control within an organization towards the tendency of fraud.

$\mathrm{H} 2$ : Exoteric religiosity moderates the relationship of internal control and the tendency of fraud in financial report. 


\subsection{Esoteric Religiosity, Internal Control and the Tendencies of Fraud in Financial Statements}

Religion plays a very important role in the formation of a person's perspective on life and behavior. This is because religion touches on the basic things in life. The relationship between religion, perspective, and life behavior of the adherents has been cultivated by philosophers and social experts as has been pointed out by Max Webber in his Protestant Ethics and the Spirit of Capitalism that the teaching of The Calling in Protestant religion which emphasizes the welfare of human life greatly influences development of capitalism at that time.

Esoteric has the meaning of aspects in the heart, essence, core or substance, as opposed to external aspects, aspects of birth, aspects of shari'a, and material aspects. The esoteric dimension is more focused on religious substances which cannot be legally captured (Siradj, 2006). The characteristic of the esoteric dimension is that individuals try to find the essence of religion. They carry the religious teachings that they believe in as much as possible into the thoughts and behaviors of everyday lives in society. Esoteric religiosity on the outline is about achievingtheperfect human(insankamil), that is spiritual man.

TPB provides an illustration that before individuals behave there are influencing factors that lead to intentions and finally behavior. Esoteric dimension is a personal search for understanding the main questions about life, about meaning, and about the relationship of sacredness. Individuals who understand the esoteric dimension will display behaviors that are in accordance with the norms and beliefs reflected in society. The more spiritual a person can be to control his behavior by avoiding illegal actions, and the esoteric dimension will contribute to one's idealism (Wahyuni et al., 2005; Salman \& Kareem, 2012; Sulistiyo, 2014).

Deep understanding of religion will also be reflected in their working lives (Weaver \&Agle, 2002). Understanding that work is a religious calling and also a kind of worship, individuals will look for the meaning in work. In order to get the meaning, they will try to understand the vision, mission and goals of the organization where they work at. They will try to be part of the work community and pursue organizational success (Podrug, 2011; Weaver \&Agle, 2002).

H3: Esoteric religiosity moderates the relationship of internal control and tendency to fraud.

\section{Research Method}

This study uses a quantitative approach with the aim of testing and analyzing the effect of the relationship of internal control on the tendency of fraud in financial report and testing and analyzing whether exoteric religiosity variables and esoteric religiosity moderate the relationship between the two. This study uses a research instrument in the form of a questionnaire with 39 samples.

Table 1. Operational Research Variables

\begin{tabular}{|c|c|}
\hline Variables & Indicators \\
\hline \multirow{6}{*}{ Internal Control (X1) } & 1. Control Environment \\
\hline & 2. $\quad$ Risk Assessment \\
\hline & 3. Control Activity \\
\hline & 4. Information \& Communication \\
\hline & 5. $\quad$ Monitoring \\
\hline & (Arens et al, 2015) \\
\hline \multirow{2}{*}{$\begin{array}{l}\text { Exoteric } \\
\text { Religiosity (X2) }\end{array}$} & 1. Implementation of Pillars of Faith and Islam \\
\hline & (Terzi et al, 2016) \\
\hline \multirow{9}{*}{$\begin{array}{l}\text { Esoteric } \\
\text { Religiosity(X3) }\end{array}$} & 1. $\quad$ Self-discipline \\
\hline & 2. Quest and search for divinity \\
\hline & 3. Anger and expansive behavior \\
\hline & 4. Self aggrandizement \\
\hline & 5. Feeling of connectedness with God \\
\hline & 6. Meanness-generosity \\
\hline & 7. Tolerance-intolerance \\
\hline & 8. Islamic practices \\
\hline & (Dasti \& Sitwat, 2014) \\
\hline \multirow{4}{*}{$\begin{array}{l}\text { Tendencies of Fraud } \\
\text { in Financial } \\
\text { Statements }(\mathrm{Y})\end{array}$} & 1. Financial statement engineering \\
\hline & 2. Deviation of assets \\
\hline & 3. Corruption \\
\hline & (Wilopo, 2006) \\
\hline
\end{tabular}

The regression equation to test the effect of internal control on the tendency of fraud in financial report with exoteric and esoteric religiosity as moderating variables according to the model in this study are as follows:

$$
\begin{aligned}
& \mathrm{Y}=\beta 0+\beta 1 \mathrm{X} 1 \\
& \mathrm{Y}=\beta 0+\beta 1 \mathrm{X} 1+\beta 2 \mathrm{X} 2+\beta 3 \mathrm{X} 1 \mathrm{X} 2+\mathrm{e}
\end{aligned}
$$




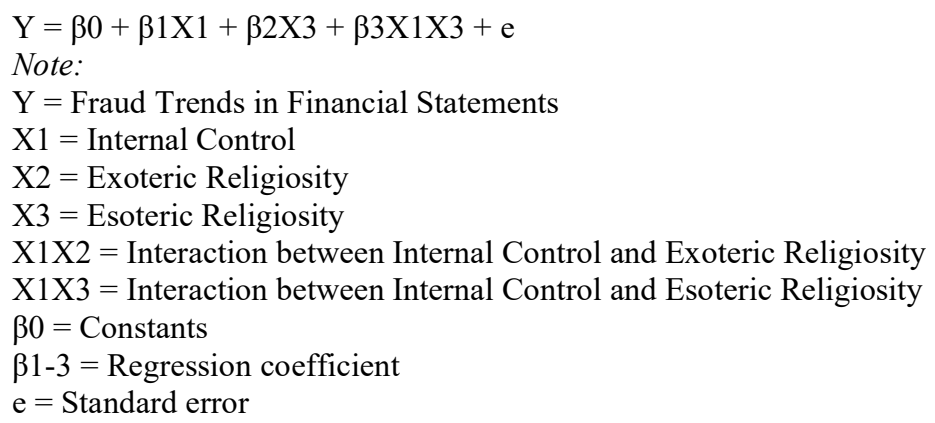

\section{Result}

\subsection{Descriptive Statistics}

Table 2. Descriptive Statistics

\begin{tabular}{|l|l|l|l|l|l|}
\hline Descriptive Statistics & N & Minimum & Maximum & Mean & Std. Deviation \\
\hline Internal Control & 39 & 80 & 115 & 97,64 & 9,895 \\
\hline Exoteric Religiosity & 39 & 30 & 45 & 42,46 & 3,210 \\
\hline Esoteric Religiosity & 39 & 200 & 344 & 286,79 & 36,163 \\
\hline Fraud Trends in Financial Statements & 39 & 17 & 25 & 21,41 & 2,917 \\
\hline Valid N (listwise) & 39 & & & & \\
\hline
\end{tabular}

Based on Table 2, it can be concluded that the internal control variables with 39 data, have a minimum value of 80.00, a maximum value of 115.00 with an average of 97.64 and a standard deviation of 9.895 . On exoteric religiosity variables with 39 data, have a minimum value of 30.00 , the maximum value of 45.00 with an average of 42.46 and a standard deviation of 3.210. On esoteric religiosity variables with 39 data has a minimum value of 200.00, the maximum value of 344.00 with an average of 286.79 and standard deviation of 36.163 . The Fraud Trend of Financial Statements, which numbered 39 data, had a minimum value of 17.00, a maximum value of 25.00 with an average of 21.41 and a standard deviation of 2.917 .

\subsection{Hypothesis Test}

5.2.1. First Regression

Table 3. Coefficient of Correlation (R) dan Coefficient of Determination $\left(\mathrm{R}^{2}\right)$

\begin{tabular}{|l|l|l|l|l|}
\hline Model Summary & \multicolumn{4}{l|}{ Std. Error of the Estimate } \\
\hline Model & R & R Square & Adjusted R Square & 1,847 \\
\hline 1 &, $772^{\mathrm{a}}$ &, 595 &, 584 & \\
\hline
\end{tabular}

Table 4. T Test

\begin{tabular}{|c|c|c|c|c|c|c|}
\hline \multicolumn{7}{|c|}{ Coefficients $^{\mathrm{a}}$} \\
\hline \multirow{2}{*}{\multicolumn{2}{|c|}{ Model }} & \multicolumn{2}{|c|}{ Unstandardized Coefficients } & Standardized Coefficients & \multirow[b]{2}{*}{$\mathrm{T}$} & \multirow[b]{2}{*}{ Sig. } \\
\hline & & $\mathrm{B}$ & Std. Error & Beta & & \\
\hline 1 & (Constant) & 11,533 & 5,018 & & 2,298 &, 027 \\
\hline & Internal Control &,- 364 & 049 & 772 & 7,377 &, 000 \\
\hline
\end{tabular}

It is known from Table 3 that the Adjusted $\mathrm{R}$ Square coefficient value is 0.584 or $58.4 \%$. This value indicates that $58.4 \%$ of Fraud Trends in Financial Statements can be explained in this research model, while the remaining $41.6 \%$ is explained by other reasons outside the model. It is known from Table 4 that the resulting regression equation is as follows:

$$
\begin{aligned}
& \mathrm{Y}=\beta 0+\beta 1 \mathrm{X} 1 \\
& \mathrm{Y}=11,533-0,364
\end{aligned}
$$

Since the significance value generated is $0,000<0,05$, it can be concluded that $\mathrm{H} 0$ is rejected and $\mathrm{H} 1$ is accepted. This shows that Internal Control (X1) influences the Fraud Trends in Financial Statements (Y).

Broken Windows theory shows that the existence of internal controls will reduce all frauds. If there is a systematic control system, it will reduce or even eliminate the opportunity to commit fraud. Fraud is contagious just like the fashion trend so that with a small start, such as breaking a window, the same action immediately spreads throughout the place. Therefore, when an organization takes precautions by having an internal control system, the tendency of fraud in financial statements will be overcome. The result of this study is consistent with the researches of Smith et al. (1997), Abbot et al. (2004), Wilopo (2006), Dewi (2014), Udayani (2017) which state that effective internal control can reduce financial report fraud. 


\subsubsection{Second Regression}

Table 5. Coefficient of Correlation( $R)$ and Coefficient of Determination $\left(\mathrm{R}^{2}\right)$

\begin{tabular}{|l|l|l|l|l|}
\hline \multicolumn{4}{|l|}{ Model Summary } \\
\hline Model & R & R Square & Adjusted R Square & Std. Error of the Estimate \\
\hline 1 &, $921^{\mathrm{a}}$ &, 848 &, 835 & 1,164 \\
\hline
\end{tabular}

Table 6. F Test with moderating variable Exoteric Religiosity (X2)

\begin{tabular}{|c|c|c|c|c|c|c|}
\hline \multicolumn{7}{|c|}{ ANOVA $^{a}$} \\
\hline \multicolumn{2}{|c|}{ Model } & Sum of Squares & df & Mean Square & $\mathrm{F}$ & Sig. \\
\hline \multirow[t]{3}{*}{1} & Regression & 264,341 & 3 & 88,114 & 65,059 &, $000^{\mathrm{b}}$ \\
\hline & Residual & 47,403 & 35 & 1,354 & & \\
\hline & Total & 311,744 & 38 & & & \\
\hline
\end{tabular}

Table 7. T Test with moderating variable Exoteric Religiosity (X2)

\begin{tabular}{|c|c|c|c|c|c|c|}
\hline \multicolumn{7}{|c|}{ Coefficients $^{\mathrm{a}}$} \\
\hline \multirow{2}{*}{\multicolumn{2}{|c|}{ Model }} & \multicolumn{3}{|c|}{ Unstandardized Coefficients $\mid \begin{array}{l}\text { Standardized } \\
\text { Coefficients }\end{array}$} & \multirow[b]{2}{*}{$\mathrm{t}$} & \multirow[b]{2}{*}{ Sig. } \\
\hline & & $\mathrm{B}$ & Std. Error & Beta & & \\
\hline \multirow[t]{4}{*}{1} & (Constant) & 92,479 & 52,996 & & 1,745 &, 090 \\
\hline & Internal Control &,- 011 & ,546 &,- 002 &,- 002 & 003 \\
\hline & Exoteric Religiosity & $-3,305$ & 1,339 & $-3,533$ & $-2,468$ & 019 \\
\hline & Internal Control x Exoteric Religiosity &,- 022 &, 014 & $-4,113$ & $-1,635$ & 006 \\
\hline
\end{tabular}

Based on Table 5, it is known that the coefficient of determination of Adjusted R Square is 0.835 or $83.5 \%$. This value indicates that $83.5 \%$ of Fraud Trends in Financial Statements (Y) can be explained in this research model, while the remaining $16.5 \%$ is explained by other reasons outside the model.

Based on Table 6, the F test in this study produces an F value of 65,059 with a significance level of 0,000 to find out what the regression model is. Since the significance value is $0,000<0,05$, this shows that the regression model can be used to predict Fraud Trends in Financial Statements (Y) or it can be said that Internal Control (X1), Exoteric Religiosity (X2) and Interactions between Internal Control and Exoteric Religiosity (X1X2) jointly influences the Financial Report Fraud Trend (Y). It is known from Table 7 that the resulting regression equation is as follows:

$$
\begin{aligned}
& \mathrm{Y}=\beta 0+\beta 1 \mathrm{X} 1+\beta 2 \mathrm{X} 2+\beta 3 \mathrm{X} 1 \mathrm{X} 2+\mathrm{e} \\
& \mathrm{Y}=92,479,0,011-3,305-0,022
\end{aligned}
$$

The variable interaction between internal control and exoteric religiosity (X1X2) gives the results of a significance level of 0.006 . Since the significance value is $0.006<0.05$ so it can be concluded that the Exoteric Religiosity variable (X2) is a moderating variable.

Exoteric traditions in religion besides aiming as a form of obedience to God, they also have social goals. The existence of merit and sin concept in the exoteric tradition is intended to inspire humans to behave socially, in other words, to behave in favor of order and productivity in society. Religious rituals as an exoteric dimension have authority to influence the behavior of adherents.

The concept of reward and sin in the exoteric dimension becomes the main driver of individuals behaving. TPB provides an illustration that before individuals behave, there are influencing factors that lead to intentions and finally behavior. One predictor that influences intention and behavior according to Ajzen(2006) is attitude toward the behavior. The more individuals have an assessment that a behavior will produce positive consequences, the individual will tend to be active towards the behavior; on the contrary, the more individuals have an assessment that a behavior will produce negative consequences, the individual will tend to reject the behavior (Ajzen, 2006).

Internal controls which are not merely policies are manual and involve various forms but involve individuals within the organization. The success of a system goes well and effectively cannot be separated by individual factors. Individuals whose ideologies and life principles are based on religious factors can strengthen internal control and prevent fraud (McGuire et al, 2011; Mukhibad, 2017).

\subsubsection{Third Regression}

Table 8. Coefficient of Correlation $(\mathrm{R})$ and Coefficient of Determination $\left(\mathrm{R}^{2}\right)$

\begin{tabular}{|l|l|l|l|l|}
\hline \multicolumn{4}{|l|}{ Model Summary } \\
\hline Model & R & R Square & Adjusted R Square & Std. Error of the Estimate \\
\hline 1 &, $777^{\text {a }}$ &, 604 &, 570 & 1,879 \\
\hline
\end{tabular}


Table 9. F Test with moderating variable Esoteric Religiosity (X3)

\begin{tabular}{|l|l|l|l|l|l|l|}
\hline \multicolumn{6}{|l|}{ ANOVA } \\
\hline \multicolumn{2}{|l|}{ Model } & Sum of Squares & df & Mean Square & F & Sig. \\
\hline \multirow{3}{*}{1} & Regression & 188,216 & 3 & 62,739 & 47,776 &, $000^{\text {b }}$ \\
\cline { 2 - 8 } & Residual & 123,527 & 35 & 3,529 & & \\
\cline { 2 - 7 } & Total & 311,744 & 38 & & & \\
\hline
\end{tabular}

Table 10. T Test with moderating variable Esoteric Religiosity (X3)

\begin{tabular}{|c|c|c|c|c|c|c|c|}
\hline \multicolumn{8}{|c|}{ Coefficients $^{a}$} \\
\hline \multirow{2}{*}{\multicolumn{3}{|c|}{ Model }} & \multicolumn{2}{|c|}{ Unstandardized Coefficients } & \multirow{2}{*}{$\begin{array}{l}\text { Standardized } \\
\text { Coefficients } \\
\text { Beta }\end{array}$} & \multirow[b]{2}{*}{$\mathrm{t}$} & \multirow[b]{2}{*}{ Sig. } \\
\hline & & & $\mathrm{B}$ & Std. Error & & & \\
\hline 2 & (Constant) & & 33,212 & 68,520 & & ,485 &, 031 \\
\hline & Internal Control & &,- 848 &, 697 & $-1,799$ &,- 216 &, 002 \\
\hline & Esoteric Religiosity & &,- 152 &, 235 &,- 902 &,- 648 &, 021 \\
\hline & $\begin{array}{l}\text { Internal Control } \\
\text { Religiosity }\end{array}$ & Esoteric &,- 036 &, 002 & $-1,513$ &,- 690 &, 003 \\
\hline
\end{tabular}

Based on Table 8, it is known that the determination coefficient of Adjusted R Square is 0.570 or $57 \%$ of this value indicates that $57 \%$ of the Fraud Trend of Financial Statements (Y) can be explained in this research model, while the remaining $43 \%$ is explained by other reasons outside the model.

Based on Table 9, the F test in this study produces an $\mathrm{F}$ value of 47,776 with a significance level of 0,000 to find out what the regression model is. Since the significance value is $0,000<0,05$, this indicates that the regression model can be used to predict Fraud Trends in Financial Statements (Y) or it can be said that Internal Control (X1), Esoteric Religiosity (X3) and Interactions between Internal Control and Esoteric Religiosity (X1X3) jointly influences the Fraud Trend of Financial Statements (Y). It is known from Table 10 that the resulting regression equation is as follows:

$$
\begin{aligned}
& \mathrm{Y}=\beta 0+\beta 1 \mathrm{X} 1+\beta 2 \mathrm{X} 3+\beta 3 \mathrm{X} 1 \mathrm{X} 3+\mathrm{e} \\
& \mathrm{Y}=33,212-0,848-0,152-0,36
\end{aligned}
$$

The variable interaction between internal control and exoteric religiosity (X1X2) gives the results of a significance level of 0.003 . Since the significance value is $0.003<0.05$ so it can be concluded that the Esoteric Religiosity variable (X3) is a moderating variable.

Religion plays a very important role in the formation of a person's perspective on life and behavior. This is because religion touches on the basic things in life. The relationship between religion, perspective, and life behavior of the adherents has been cultivated by philosophers and social experts as has been pointed out by Max Webber in his Protestant Ethics and the Spirit of Capitalism that the teaching of The Calling in Protestant religion which emphasizes the welfare of human life greatly influences development capitalism at that time.

Esoteric has the meaning of aspects in the heart, essence, core or substance, as opposed to external aspects, aspects of birth, aspects of shari'a, and material aspects. Esoteric dimension is more focused on religious substances which cannot be legally formal (Siradj, 2006). The characteristic of the esoteric dimension is that individuals try to find the essence of religion. They carry the religious teachings that they believe in as much as possible into the thoughts and behaviors of everyday life in society. Esoteric religiosity on the outline is about achieving the perfect human (insankamil), that is spiritual man.

The esoteric dimension is a personal search for understanding the main questions about life, about meaning, and about the relationship of sacredness. Individuals who understand the esoteric dimension will display behaviors that are in accordance with the norms and beliefs reflected in society. The more spiritual a person can be to control his behavior by avoiding illegal actions, and the esoteric dimension will contribute to one's idealism (Wahyuni et al., 2005; Salman \& Kareem, 2012; Sulistiyo, 2014).

Deep understanding of religion will also be reflected in their working lives (Weaver \&Agle, 2002). Understanding that work is a religious calling and also a kind of worship, individuals will look for meaning in work. To get the meaning, they will try to understand the vision, mission and goals of the organization in where they work at. They will try to be part of the work community and position themselves as stewards who pursue organizational success (Podrug, 2011; Weaver \&Agle, 2002).

\section{Conclusion}

Based on the results of testing, it can be concluded that (1) internal control has a negative effect on the tendency of fraud in financial report. This means that with increasing internal control, the tendency of fraud in financial report will decrease, (2) exoteric religiosity moderates the relationship of internal control to financial statement fraud. This means that the existence of exoteric religiosity reinforces the relationship of internal control to the 
tendency of fraud in financial report and (3) esoteric religiosity moderates the relationship of internal control to financial statement fraud. This means that the existence of esoteric religiosity strengthens the relationship of internal control to the tendency of fraud in financial report.

This study has several limitations.Among others, first, observations were made using only data from one institution. Second, the measurement of the variables in this study uses employee perceptions through selfassessment so that there is a possibility when filling out questionnaires, they did not do it truthfully or just made good judgments for themselves.

\section{References}

Abbott, L.J., Parker, S. and Peters, G.F., 2004. Audit committee characteristics and restatements. Auditing: A Journal of Practice \& Theory, 23(1), pp.69-87.

ACFE. 2016. Fraud Examiners Manual. Texas: Association of Certified Fraud Examiner.

Ajzen, Icek. 2006. The Influence of Attitudes on Behavior. NJ: Lawrence Erlbaum Associates

Albrecht, W.S., Albrecht, C.O., Albrecht, C.C. and Zimbelman, M.F., 2011. Fraud Examination. Cengage Learning.

Al-Aidaros, Al-Hasan Mohammed Hasan. 2012. The Accountant's Ethical Code of Conduct and Moral Reasoning from an Islamic Environment: Case in Yemen. Thesis Submitted to Othman Yeop Abdullah Graduate School of Business, Universiti Utara Malaysia.

Arens A. Alvin. Ellder J. Ronald \& Beasley Mark S. 2015. Auditing dan Jasa Assurance Pendekatan Terintegrasi. Jakarta: Erlangga.

Braga, Anthony and Brandon C. Welsh. 2016. Broken Windows Policing to Reduce Crime, The Campbell Collaboration

Brick, I.E. and Chidambaran, N.K., 2008. Board monitoring, firm risk, and external regulation. Journal of Regulatory Economics, 33(1), pp.87-116.

Carmona, S. and Ezzamel, M., 2006. Accounting and religion: a historical perspective. Accounting History, 11(2), pp.117-127.

Dasti, R. and Sitwat, A. 2014. Development of a multidimensional measure of islamic spirituality (MMS). Journal of Muslim Mental Health, 8(2).

Darviri, Christina, P. Darvyri, M. Galanakis. 2014. The Revised Intrinsic/Extrinsic Religion Orientation. Published Online in SciRes.

Dewi, Gusti. 2014. Pengaruh Moralitas Individu dan Pengendalian Internal pada Kecurangan Akuntansi (Studi Eksperimen pada Pemerintah Daerah Provinsi Bali). Tesis Universitas Udayana

Donaldson, L. and Davis, J.H., 1991. Stewardship theory or agency theory: CEO governance and shareholder returns. Australian Journal of management, 16(1)

Durkheim, Emile. 2011. The Elementary Forms of the Religious Life. Jakarta: Penerbit Diva Press.

Dyreng, S.D., Mayew, W.J. and Williams, C.D., 2012. Religious social norms and corporate financial reporting. Journal of Business Finance \& Accounting, 39(7 - 8), pp.845-875.

Fama, E, 1980. Agency Problems and The Theory of The Firm. Journal of Political Economy. Vol.88.

Ghozali, Imam. 2016. Aplikasi Analisis Multivariate Dengan Program IBM. SPSS 19. Semarang: Universitas Diponegoro.

Gray, S.J. 1988. Towards a theory of cultural influence on the development of accounting systems internationally. Journal Abacus 24(1).

Hamid, S., Craig, R. and Clarke, F. 1993. Religion: A Confounding Cultural Element in the International Harmonisation of Accounting. Journal Abacus 29(2).

Hernandez, J. R. dan T. Groot. 2007. Corporate Fraud: Preventive Controls Which Lower Fraud Risk. Amsterdam Research Centre in Accounting.

Lewis , Mervyn. 2011. Islam and Accounting. Accounting Forum 25(2):103 - 127.

McGuire, S.T., Omer, T.C. and Sharp, N.Y., 2011. The impact of religion on financial reporting irregularities. The Accounting Review, 87(2), pp.645-673.

Mukhibad, Hasan. 2017. Maintaining Employees' Morality to Improve Internal Control In The Sharia Microfinance Institution. Jurnal Walisongo Vol. 25 No.2.

Mumtaz, Majid. 2018. Broken Windows - An Ignored Perspective on Control Environment.

Perera, M.H.B. 1989. Towards a Framework to Analyse the Impact of Culture on Accounting. International Journal of Accounting 4(1).

Podrug, N. 2011. The strategic role of managerial stewardship behaviour for achieving corporate citizenship. Ekonomski pregled, 62(7-8).

Ritzer, George. 1988. Early Modern Social Theory: Selected Interpretative Readings. Toronto: Canadian Scholars Press Inc.

Salman, Farooq dan Haris Kareem. 2012. The Role of Islamic Ethics in Accounting Environment. IOSR Journal 
of Business and Management Volume 2, Issue 1, PP 26-30.

Schuon, F., 1998. Islam dan filsafat perenial. Bandung: Mizan.

Siradj, Said Aqil., 2006. Tasawuf sebagai kritik sosial. Bandung, PT Mizan Pustaka.

Smith, R., Tiras, Sam., and Vichitlekarn, Stan, 1997. The Interaction Between Internal Control Assessment and Substantive Testing in Audits for Fraud. Social Science Research Network.

Sulistiyo, Heru. 2014. Relevansi Nilai Religius Dalam Mencegah Perilaku Disfungsional Audit. Jurnal Ekonomi Manajemen dan Akuntansi No. 36 / Th. XXI.

Terzi, H., Alserhan, B.A. and Altunişik, R. 2016. The relationship between religiosity and consumer behaviour: Measure of Islamic religiosity. International Journal of Teaching and Case Studies, 7(3-4)

Triyuwono, Iwan, Ali Djamhuri, Aji Dedi Mulawarman, dan Darsono Prawironegoro. 2016. Filsafat Ilmu Akuntansi: Berpikir Kontemplatif, Holistik Intuitif, Imajinatif, Kreatif, Rasional, dan Radikal dalam Akuntansi. Jakarta: Mitra Wacana Media.

Udayani, Anak Agung. 2017. Pengaruh Pengendalian Internal dan Moralitas Individu pada Kecenderungan Kecurangan Akuntansi. Jurnal Akuntansi Universitas Udayana Vol.18.3

Wahyuni, Zulfa Indira, Yufi Adriani, and Zahrotun Nihayah. 2015. The Relationship between Religious Orientation, Moral Integrity, Personality, Organizational Climate and Anti Corruption Intentions in Indonesia. International Journal of Social Science and Humanity, Vol. 5, No. 10.

Weaver, G and Agle, B., 2002, "Religiosity and ethical behaviour in organizations: A symbolic interactionist perspective," Academy of Management Review, Vol.27, No.1

Weber, Max, 2001, Etika Protestan dan Semangat Kapitalisme, Pustaka Promethea

Wilopo. 2006. Analisis Faktor-Faktor yang Berpengaruh Terhadap Kecenderungan Kecurangan Akuntansi. Simposium Nasional Akuntansi 9. Padang. 